\title{
Pengendalian Persediaan Obat dengan Minimum-Maximum Stock Level di Instalasi Farmasi RSUP Dr. Sardjito Yogyakarta
}

\author{
Inventory Control of Medicine with Minimum-Maximum Stock Level Method in Dr. Sardjito Hospital \\ Pharmacy Yogyakarta
}

Titik Rahayu Indarti ${ }^{1}$, Satibi $^{2 *}$, Endang Yuniarti ${ }^{3}$

1. Mahasiswa Magister Manajemen Farmasi, Fakultas Farmasi, Universitas Gadjah Mada Yogyakarta, dan Staf RSUP

Dr. Sardjito Yogyakarta

2. Fakultas Farmasi, Universitas Gadjah Mada, Yogyakarta

3. RS PKU Muhammadiyah Yogyakarta

Submitted: 4-23-2019 Revised: 7-19-2019

Accepted: 7-29-2019

Korespondensi : Satibi: Email : satibi@ugm.ac.id

\begin{abstract}
ABSTRAK
Pengendalian persediaan obat yang tidak tepat dapat menyebabkan kekurangan atau kelebihan stok, hal ini menjadi perhatian penting oleh RSUP Dr. Sardjito Yogyakarta. Tujuan penelitian ini untuk mengetahui pengaruh metode Minimum-Maximum Stock Level (MMSL) pada efisiensi dan efektifitas persediaan obat di Instalasi Farmasi RSUP Dr. Sardjito Yogyakarta. Quasi eksperimental nonequivalent without control group design diterapkan, sampel diambil secara purposive dari data retrospektif bulan Januari - Juni 2018 dan penerapan metode secara prospektif yaitu bulan Agustus - Desember 2018. Tiga puluh lima jenis obat yang memenuhi kriteria inklusi serta eksklusi yaitu high cost, high volume, clinically important drug, dan supply focus pada obat kategori A hasil analisa ABC menjadi sampel penelitian ini. Dilakukan analisa data nilai persediaan, nilai dan kejadian stock out, serta ITOR (Inventory Turn Over Ratio) sebelum dan sesudah penerapan metode menggunakan uji statistik Wilcoxon Signed Rank Test dan Mc Nemar. Hasil uji menunjukkan pengaruh penerapan metode pada nilai persediaan sebelum intervensi Rp5.009.221.204 dan sesudah intervensi Rp2.871.879.269 dengan nilai $p=0,007<0,05$, sedangkan nilai ITOR per tahun sebelum intervensi 20,776 kali/tahun dan sesudah intervensi $8,494 \mathrm{kali} /$ tahun dengan nilai $p=0,003<0,05$, serta kejadian stock out sebelum intervensi 8 kali menjadi 2 kali sesudah intervensi dengan nilai $p=0,03<0,05$, untuk nilai stock out sebelum intervensi Rp75.569.317 dan sesudah intervensi Rp46.346.300 dengan nilai $p=0,068>0,05$. Penerapan metode memberikan dampak positif terhadap efisiensi dan efektifitas pengendalian obat dengan turunnya nilai persediaan dan kejadian stock out, serta menurunkan ITOR menjadi lebih ideal.
\end{abstract}

Kata kunci: MMSL; persediaan; stock out; ITOR

\section{ABSTRACT}

Inappropriate inventory control of medicines in hospital can lead to shortage or over stock, which is a problem faced by Dr. Sardjito Hospital Yogyakarta. The aim of this study was to examine the effect of the Minimum-Maximum Stock Level (MMSL) method on efficiency and effectivity of medicine inventory at Hospital Pharmacy Dr. Sardjito. A quasi experimental nonequivalent without control group design was applied, and purposive sampling was taken from retrospective data in January-June 2018 and the application of methods prospectively i.e. August-December 2018. Thirty-five types of medicines which met the inclusion and exclusion criteria were obtained, i.e. high cost, high volume, clinicaly important, and supply focus. These types of medicines were included in category A of ABC Pareto Analysis. The effect of minimum-maximum stock level method on inventory value, stock out value, and Inventory Turn Over Ratio (ITOR) was analysed using Wilcoxon Signed Rank Test statistic. The effect of minimum-maximum stock level method on stock out incident was analysed using Mc Nemar Test statistic. This study found that minimum-maximum stock level method to impact the positively their efficiency of drug control marked by decreased of inventory value and ITOR ideal value. The effectiveness of drug control marked by decreased incidence of stock out in Hospital Pharmacy Departement Dr. Sardjito.

Keywords: MMSL; inventories; stock outs; ITOR 


\section{PENDAHULUAN}

Farmasi rumah sakit mempunyai peran yang sangat penting dalam aspek manajemen (pengelolaan obat) maupun pelayanan kefarmasian dan saling terkait dalam seluruh sistem pelayanan di rumah sakit ${ }^{1}$. Pengelolaan obat yang efisien merupakan salah satu faktor yang sangat penting dalam keberhasilan manajemen secara keseluruhan, serta bertujuan untuk terjaminnya ketersediaan obat yang bermutu baik, secara tepat jenis, tepat jumlah, tepat waktu serta digunakan secara rasional sehingga dana yang tersedia dapat digunakan dengan sebaik-baiknya dan berkesinambungan guna memenuhi kepentingan masyarakat yang berobat ke unit pelayanan kesehatan².

Di banyak negara berkembang belanja obat di rumah sakit dapat menyerap sekitar 40-50\% biaya keseluruhan rumah sakit. Belanja obat yang demikian besar tentunya harus dikelola dengan efektif dan efisien, hal ini diperlukan mengingat dana kebutuhan obat di rumah sakit tidak selalu sesuai dengan kebutuhan riil pelayanan. Kondisi di atas tentunya harus disikapi dengan sebaikbaiknya ${ }^{3}$. Saat ini pada tataran global telah dirintis program Good Governance in Pharmaceutical Sector atau lebih dikenal dengan Tata Kelola Obat yang Baik di Sektor Farmasi. Indonesia termasuk salah satu negara yang berpartisipasi dalam program ini bersama 19 negara lainnya. Pemikiran tentang perlunya tata kelola obat yang baik di sektor farmasi berkembang mengingat banyaknya praktek ilegal di lingkungan kefarmasian mulai dari clinical trial, riset dan pengembangan, registrasi, pendaftaran, paten, produksi, penetapan harga, visibilitas persediaan, peramalan kebutuhan, pengadaan, seleksi distribusi dan trasportasi ${ }^{4}$. Saat ini, semua rumah sakit mempertahankan metode pengendalian persediaan mereka sendiri, tetapi mereka masih mengalami masalah dalam mencapai manajemen persediaan yang efektif. Untuk mencapai efisiensi, suplai obat perlu dikelola dalam semua aspek untuk mengatasi kelebihan stok, kadaluwarsa, rantai pasokan dan lain-lain.
Instalasi farmasi adalah daerah di mana alternatif dan kompromi tidak diterima ketika stock out muncul, karena akan mengakibatkan biaya perawatan kesehatan meningkat, dan rumah sakit dituntut untuk memberikan kualitas perawatan, dengan tetap mempertimbangkan penghematan biaya kesehatan dan hal ini dapat dicapai salah satunya dengan meningkatkan efisiensi rantai pasokan ${ }^{4}$. Pengendalian persediaan obat bertujuan untuk menciptakan keseimbangan antara persediaan dengan permintaan. Fungsi pengendalian sangat penting untuk menjamin efekfitas dan efisiensi pengelolaan persediaan obat itu sendiri ${ }^{5}$. Parameter keberhasilannya dapat dilihat dari indikator efisiensi dan efektivitas pengendalian persediaan yang diterapkan. Indikator yang dimaksud adalah sebagai berikut: a) Indikator efisiensi yaitu ketepatan perencanaan yaitu dengan melihat dari satu jenis obat obat dalam perencanaan dengan jumlah barang dan jenis obat tersebut dalam kenyataan pemakaian, kecukupan obat yaitu jumlah bulan yang menunjukkan antisipasi lamanya stok obat yang tersedia, stok berlebih yaitu stok obat yang kecukupan obatnya lebih dari 18 bulan, TOR (Turn Over Ratio) yaitu perputaran modal yang terjadi selama 1 tahun, stok mati yaitu stok obat yang dalam waktu 3 bulan atau lebih tidak dipakai, b) Indikator efektivitas adalah stok kosong yaitu jumlah stok akhir adalah 0 (nol) atau stock out ${ }^{6}$.

Tujuan dari pengendalian persediaan obat yang lain adalah untuk membuat persediaan yang dapat meminimalkan nilai dan kejadian stock out, hal ini tidak boleh disamakan dengan meminimalkan persediaan ${ }^{7}$. Persediaan obat yang terlalu banyak akan memerlukan tempat serta biaya penyimpanan yang besar dan barang yang tersimpan tersebut merupakan modal yang perputarannya berhenti. Sedangkan, jika terlalu sedikit kemungkinan akan ada resep yang tidak terlayani karena persediaan mengalami stockout sehingga berakibat pada merosotnya mutu pelayanan rumah sakit khususnya instalasi farmasi ${ }^{8}$. Dibeberapa negara terjadinya kekosongan (stock out) obat- 
obatan esensial di tingkat klinik merupakan hal yang penting dan diakui secara luas sebagai masalah kesehatan masyarakat di Afrika dengan dampak negatif yang ditimbulkan pada morbiditas, mortalitas dan epidemiologi penyakit. Banyak kemungkinan penyebabnya adalah pada pendanaan dan proses pengadaan, kapasitas pasokan, infrastruktur dan sumber daya distribusi, metode perencanaan, sumber daya manusia dan koordinasi antar lembaga yang terkait ${ }^{9}$. Berbagai metode pengendalian persediaan obat dapat diterapkan di instalasi farmasi rumah sakit, salah satunya adalah metode MMSL (Minimum-Maximum Stock Level). Metode MMSL (Minimum-Maximum Stock Level) ini adalah metode yang paling sederhana dalam pengendalian persediaan obat yang dapat diterapkan di instalasi farmasi rumah sakit ${ }^{10}$. Beberapa metode pengendalian persediaan lain seperti model EOQ (Economic Order Quantity) klasik yang menggunakan asumsi permintaan konstan, waktu tunggu konstan, biaya pesanan tetap per pesanan, penambahan sesaat, tidak adanya stock out, tidak ada ketidakpastian permintaan dan tidak ada diskon kuantitas belum bisa sepenuhnya diterapkan di instalasi farmasi rumah sakit ${ }^{11}$.

Beberapa permasalahan penting pada tahun 2017 terkait dengan pengendalian persediaan di rumah sakit adalah adanya kekosongan obat (stock out) pada beberapa jenis obat, nilai persediaan yang tinggi di akhir tahun, serta ITOR (Inventory Turn Over Ratio) yang rendah, dan juga belum adanya metode pengendalian persediaan tertentu di instalasi farmasi, maka hal ini mendorong dilakukannya penelitian untuk mengetahui pengaruh penerapan metode minimummaximum stock level atau stok minimal (Smin) dan stok maksimal (Smak) pada efisiensi dan efektifitas pengendalian persediaan obat di Instalasi Farmasi RSUP Dr. Sardjito Yogyakarta.

\section{METODE}

Penelitian ini merupakan penelitian quasi eksperimental dengan nonequivalent without control group design. Penentuan sampel secara purposive yang diambil dari data retrospektif bulan Januari - Juni 2018 dan data penerapan metode diambil secara prospektif yaitu bulan Agustus - Desember 2018. Jumlah sampel penelitian adalah 35 jenis obat kategori A kriteria tertentu hasil dari analisa $\mathrm{ABC}$, dengan kriteria inklusi adalah obat high cost, high volume, clinically important drug (obat yang masuk Formularium Nasional tahun 2018), dan kriteria eksklusinya adalah obat dengan pasokan yang tidak stabil (supply focus) yang dilihat dari data pembelian obat di instalasi farmasi RSUP Dr. Sardjito selama bulan Januari- Juni 2018. Variabel yang diteliti adalah nilai persediaan, nilai dan kejadian stock out, serta ITOR (Inventory Turn Over Ratio) obat yang masuk dalam kategori A tersebut di Instalasi Farmasi Rumah Sakit Umum Pusat Dr. Sardjito Yogyakarta. Analisa data menggunakan uji statistik Wilcoxon Signed Ranks Test serta Mc Nemar karena data tidak terdistribusi normal dan homogen, dengan menganalisa hasil sebelum dan sesudah penerapan minimum-maximum stock level pada obat sampel.

\section{HASIL DAN PEMBAHASAN}

Analisis ABC dan Suplai Obat dari Supplier Periode Januari - Juni 2018 Untuk Penetapan Sampel Penelitian

Sebelum dilakukan penerapan

Minimum-Maximum Stock Level (MMSL), data penggunaan obat selama bulan Januari - Juni 2018 dilakukan analisis ABC atau analisis Pareto untuk mendapatkan obat yang masuk kategori A kriteria tertentu sesuai kriteria inklusi (high cost, high volume, clinically important drug) serta analisis supply focus untuk memastikan kestabilan suplai obat selama tahun 2018 dan ketidakstabilan suplai dari pemasok ini menjadi kriteria eksklusi. Didapat sampel penelitian sejumlah 35 jenis obat. Obat tersebut memiliki nilai kumulatif pemakaian antara $0-80 \%$. Jenis obat tersebut disajikan pada (Tabel I).

Nilai investasi yang besar pada obat kategori A di atas yaitu sekitar 79,9\% dari total biaya persediaan obat di instalasi farmasi rumah sakit, maka hal ini menjadikan satu 
Titik Rahayu Indarti, et al

Tabel I. Hasil Analisis ABC Periode Januari - Juni 2018 Untuk Penetapan Sampel Penelitian

\begin{tabular}{|c|c|c|c|c|c|}
\hline \multirow[b]{2}{*}{ Kategori } & \multicolumn{2}{|l|}{ Obat } & \multirow[b]{2}{*}{$\begin{array}{c}\text { Persentase } \\
\text { Jumlah } \\
\text { Total }\end{array}$} & \multirow[b]{2}{*}{$\begin{array}{l}\text { Nilai Investasi } \\
\text { (Rp) }\end{array}$} & \multirow[b]{2}{*}{$\begin{array}{c}\text { Persentase } \\
\text { Kumulatif } \\
\text { Investasi }\end{array}$} \\
\hline & Kelompok & $\begin{array}{c}\text { Jumlah } \\
\text { Jenis } \\
\text { obat }\end{array}$ & & & \\
\hline \multirow[t]{19}{*}{ A } & Kemoterapi & 29 & $3,4 \%$ & 55.104 .526 .800 & 54,26 \\
\hline & Human albumin & 7 & $0,8 \%$ & 4.372 .795 .480 & 4,31 \\
\hline & Cairan infus & 6 & $0,7 \%$ & 2.055.140.618 & 2,02 \\
\hline & Antihemofili faktor VIII/IX & 5 & $0,6 \%$ & 2.954 .236 .000 & 2,91 \\
\hline & Agen perdarahan & 4 & $0,5 \%$ & 1.497.419.345 & 1,47 \\
\hline & Insulin & 3 & $0,4 \%$ & 928.718 .544 & 1,00 \\
\hline & Immunosupresan & 4 & $0,5 \%$ & 2.209 .003 .200 & 2,18 \\
\hline & Analgetika narkotika & 2 & $0,2 \%$ & 2.269 .848 .620 & 2,24 \\
\hline & Anestesi umum & 2 & $0,2 \%$ & 962.653 .186 & 1,10 \\
\hline & Antivirus & 2 & $0,2 \%$ & 863.964 .100 & 0,90 \\
\hline & Obat thalasemia & 2 & $0,2 \%$ & 1.516 .980 .000 & 1,49 \\
\hline & Penghambat pompa proton & 1 & $0,12 \%$ & 859.745 .640 & 0,85 \\
\hline & Immunoglobulin & 1 & $0,12 \%$ & 281.281 .000 & 0,28 \\
\hline & Antijamur & 1 & $0,12 \%$ & 282.577 .500 & 0,28 \\
\hline & Antibiotika & 1 & $0,12 \%$ & 218.603 .682 & 0,22 \\
\hline & Analgetika antipiretika & 1 & $0,12 \%$ & 275.557.545 & 0,27 \\
\hline & Susunan saraf pusat & 1 & $0,12 \%$ & 196.401.535 & 0,19 \\
\hline & Obat jantung & 2 & $0,2 \%$ & 429.259 .108 & 0,42 \\
\hline & Sub Total Kategori A & 74 & $8,6 \%$ & 77.278.711.906 & $79,9 \%$ \\
\hline B & & 147 & $17,4 \%$ & 14.585.587.885 & $15,05 \%$ \\
\hline \multirow[t]{2}{*}{$\mathrm{C}$} & & 638 & $74 \%$ & 9.684.326.535 & $5,05 \%$ \\
\hline & Total & 859 & $100 \%$ & 101.548.626.326 & $100 \%$ \\
\hline
\end{tabular}

perhatian penting untuk dilakukannya penerapan metode pengendalian persediaan obat. Tidak semua jenis obat obat yang ada di instalasi farmasi Rumah Sakit Dr. Sardjito digunakan sebagai sampel penelitian, mengingat banyaknya jenis obat obat yang ada dan faktor pasokan atau suplai obat dari supplier yang banyak mengalami kendala ketersediaan, maka sampel penelitian ini berfokus pada clinically important drug yaitu obat yang masuk formularium nasional (sebagian besar pasien atau sekitar $99 \%$ adalah pasien Jaminan Kesehatan Nasional menggunakan BPJS), obat kategori A (high volume dan high cost) yaitu dengan jumlah dan nilai pemakaian yang tinggi dan melihat pasokan dari supplier yang stabil selama bulan Januari - Juni 2018. Hal ini sejalan menurut $\mathrm{WHO}^{12}$, ada empat strategi dalam pengadaan obat yang baik yaitu pengadaaan obat-obatan dengan harga mahal dengan jumlah yang tepat dalam penelitian dipilih obat kategori A (high volume dan high cost); seleksi terhadap supplier yang dapat dipercaya dengan produk yang berkualitas, dalam penelitian dilakukan evaluasi terhadap pemenuhan suplai dari supplier yaitu kesesuaian antara jumlah pesanan dan jumlah penerimaan; pastikan ketepatan waktu pengiriman obat, dalam penelitian dilakukan analisa waktu tunggu pemasok (supplier lead time) untuk bisa memperhitungkan stok pengaman (safety stock); mencapai kemungkinan termurah dari harga total, dalam hal ini pengendalian dari sisi obat yang masuk formularium nasional dan masuk katalog elektronik.

Analisis suplai obat dari pemasok (supply focus) pada 74 jenis obat yang masuk 
kategori A (high cost, high volume) serta clinically important drug (masuk formularium nasional tahun 2018) di dapat hasil 35 jenis obat yang suplainya stabil pada periode bulan Januari - Juni 2018. Suplai stabil yang dimaksud adalah terdapat kesamaan jumlah antara jumlah pesanan dengan jumlah penerimaan atau pengiriman dari supplier atau distributor. Data ini diambil dari data pemesanan dan penerimaan di gudang farmasi RSUP Dr. Sardjito dari bulan Januari Juni 2018. Dari 74 jenis obat kategori A, pada 39 jenis obat yang tidak stabil suplainya sebagian besar adalah obat - obat yang masuk dalam kelompok obat kemoterapi, diikuti obat antikoagulan, antibiotika dan obat antivirus. Jenis obat yang dijadikan sampel penelitian sebanyak 35 jenis obat disajikan pada (Tabel II).

Berdasar Tabel II dapat diketahui obat kemoterapi masih mendominasi jenis obat pada sampel penelitian. Berdasarkan data kestabilan suplai dari pemasok dilakukan penghitungan waktu tunggu (supplier lead time) pada saat pembelian yang dihitung dari tanggal pesanan sampai dengan tanggal penerimaan. Data lead time ini bisa digunakan sebagai dasar evaluasi supplier dan untuk menghitung stok pengaman (safety stock). Dari data perhitungan supplier lead time pada 35 sampel penelitian didapat hasil bahwa 45,72\% supplier mengirim obat ke gudang farmasi kurang dari 1 minggu setelah dikirimkannya surat perintah (SP) dari instalasi farmasi, hal ini menunjukkan adanya perhatian dari supplier untuk segera mengirim pesanan obat dari instalasi farmasi sehingga tidak terjadi stockout. Apabila pemasok (supplier) kurang bertanggung jawab dan tidak respon terhadap pemenuhan permintaan maka akan menimbulkan masalah antara lain terjadinya stockout dan lamanya lead time ${ }^{13}$. Pemilihan pemasok (supplier) ini tidak hanya dilakukan bagi perusahaan yang memproduksi barang saja akan tetapi juga bisa dilakukan pada beberapa instansi pemerintahan yang melakukan pemilihan pemasok $^{14}$. Permasalahan suplai dari pemasok ini menjadi permasalahan penting di instalasi farmasi rumah sakit sejak diberlakukannya program pemerintah yaitu program nasional Jaminan Kesehatan Nasional, dimana pasien BPJS yang menggunakan haknya dirawat di rumah sakit harus menggunakan obat yang masuk formularium nasional dan implementasi penggunaan formularium nasional ini dijadikan indikator kinerja Direktur Utama Rumah Sakit Umum Pusat Dr. Sardjito, hal ini pulalah yang menjadi dasar pemilihan sampel penelitian yaitu hanya obat yang masuk formularium nasional. Pengendalian harga dan ketersediaan obat yang ada dalam formularium nasional menggunakan ecatalogue ${ }^{15}$.

Berdasarkan data jenis obat beserta lead time selanjutnya dilakukan penghitungan stok pengaman (safety stock), stok minimal (minimum stock) dan stok maksimal (maximum stock) dengan melihat rata-rata penggunaan harian yang diperoleh dari data penggunaan bulan Agustus sampai dengan Oktober 2018 dikarenakan mulai pertengahan bulan Agustus terdapat adanya penambahan pelayanan farmasi rawat inap di Pelayanan Jantung Terpadu dan mengakibatkan adanya peningkatan jumlah pemakaian obat yang cukup banyak dibanding periode Januari Juni 2018 dan periode pengadaan yang telah ditetapkan yaitu 90 hari. Hasil penghitungan tersebut dijadikan dasar penerapan metode pemesanan menggunakan MinimumMaximum Stock Level (MMSL).

Rumus yang digunakan untuk menghitung adalah sebagai berikut ${ }^{6}$ :

Safety stock $(\mathrm{SS})=\mathrm{LT} \times \mathrm{CA}$

Smin $($ Stok minimal $)=(\mathrm{LT} \times \mathrm{CA})+\mathrm{SS}=2 \mathrm{SS}$

Smak $($ Stok maksimal $)=\operatorname{Smin}+(\mathrm{PP} \times \mathrm{CA})$

Keterangan: $\mathrm{LT}=$ Lead Time $=$ waktu tunggu pesanan; $\mathrm{CA}=$ Consumption Average $=$ rata-rata penggunaan per hari; $\mathrm{PP}=$ Procurement Period (periode pengadaan).

\footnotetext{
Inventory Turn Over Ratio $(\mathrm{ITOR})=$ Harga pokok penjualan $(\mathrm{HPP})$ Rata-rata Nilai Persediaan Nilai HPP (Harga Pokok Penjualan) = Jumlah Pemakaian $x$ Harga dasar Nilai Rata-rata Nilai Persediaan $=\{$ Persediaan Awal + Akhir $) \times$ Harga dasar
} 
Tabel II. Daftar Obat Sampel Penelitian Hasil Analisis ABC Dan Kestabilan Suplai Obat dari Supplier Periode Januari - Juni 2018

\begin{tabular}{|c|c|c|}
\hline No & Nama Obat & Nama Generik \\
\hline 1 & Alimta inj $500 \mathrm{mg}$ & Pemetrekset serb inj 500 mg \\
\hline 2 & Aminofluid inf , $500 \mathrm{ml}$ & $\begin{array}{l}\text { Asam Amino } 30 \mathrm{~g} \text {, Glukosa 7,3\% dan elektrolit inf } 500 \\
\mathrm{ml}\end{array}$ \\
\hline 3 & Aricept Evess tab $10 \mathrm{mg}$ & Donepezil $\mathrm{HCl}$ tab $10 \mathrm{mg}$ \\
\hline 4 & Aromasin tab $25 \mathrm{mg}$ & Exemestane tab $25 \mathrm{mg}$ \\
\hline 5 & Avastin inj $25 \mathrm{mg} / \mathrm{mL}, 4 \mathrm{ml}$ & Bevacizumab inj $25 \mathrm{mg} / \mathrm{ml}$ \\
\hline 6 & Belloxa inj $100 \mathrm{mg}$ & Oxaliplatin inj $100 \mathrm{mg}$ \\
\hline 7 & $\begin{array}{l}\text { Clinimix N9G15E inf , } 1000 \\
\mathrm{ml}\end{array}$ & $\begin{array}{l}\text { Asam amino } 28 \mathrm{gr} / \mathrm{L} \text {, Glukosa } 75 \mathrm{gr} / \mathrm{L} \text {, elektrolit, inf } \\
1000 \mathrm{ml}\end{array}$ \\
\hline 8 & Cytarabin DBL inj $1 \mathrm{~g}, 10 \mathrm{ml}$ & Cytarabin inj $1 \mathrm{~g} / 10 \mathrm{ml}$ \\
\hline 9 & Erbitux inj $5 \mathrm{mg} / \mathrm{mL}, 20 \mathrm{ml}$ & Cetuximab inj $5 \mathrm{mg} / \mathrm{ml}$ \\
\hline 10 & Fentanyl inj $50 \mathrm{mcg} / \mathrm{mL}, 2 \mathrm{ml}$ & Fentanyl inj $50 \mathrm{mcg} / \mathrm{ml}, 2 \mathrm{ml}$ \\
\hline 11 & Ferriprox tab $500 \mathrm{mg}$ & Deferasirox tab $500 \mathrm{mg}$ \\
\hline 12 & Gammaraas inj $2.5 \mathrm{~g}, 50 \mathrm{ml}$ & Immune globulin iv inj $50 \mathrm{mg} / \mathrm{ml}, 50 \mathrm{ml}$ \\
\hline 13 & Gemedac inj $1000 \mathrm{mg}$ & Gemcitabine $\mathrm{HCl}$ inj $1 \mathrm{~g}$ \\
\hline 14 & Glivec tab $100 \mathrm{mg}$ & Imatinib mesylate tab $100 \mathrm{mg}$ \\
\hline 15 & Haemoctin inj $1000 \mathrm{IU}$ & Antihemophilic factor VIII inj 1000 UI \\
\hline 16 & Holoxan inj $1 \mathrm{~g}$ & Ifosfamide inj $1 \mathrm{~g}$ \\
\hline 17 & $\begin{array}{l}\text { Human Albumin Biotest inf } \\
20 \%, 100 \mathrm{ml}\end{array}$ & Human Albumin inf 20\%, $100 \mathrm{ml}$ \\
\hline 18 & Koate inj $1000 \mathrm{IU}$ & Antihemophilic factor VIII inj $1000 \mathrm{UI}$ \\
\hline 19 & Koate inj 500 IU & Antihemophilic factor VIII inj 480 - 600 UI \\
\hline 20 & Mabthera inj $100 \mathrm{mg}, 10 \mathrm{ml}$ & Rituximab inj $100 \mathrm{mg} / 10 \mathrm{ml}$ \\
\hline 21 & Mabthera inj $500 \mathrm{mg}, 50 \mathrm{ml}$ & Rituximab inj $500 \mathrm{mg} / 50 \mathrm{ml}$ \\
\hline 22 & Mycamine inj $50 \mathrm{mg}$ & Mycafungin inj $50 \mathrm{mg}$ \\
\hline 23 & $\begin{array}{l}\text { Novomix } 30 \text { FlexPen inj } 100 \\
\mathrm{iu} / \mathrm{ml}, 3 \mathrm{ml}\end{array}$ & $\begin{array}{l}\text { Analog insulin mix acting inj } 100 \mathrm{UI} / \mathrm{ml} \text { (Premix } 30 \% \\
\text { Insulin Aspart }+70 \% \text { Protaminated Insulin Aspart } \\
\text { (Analogue)) } 3 \mathrm{ml}\end{array}$ \\
\hline 24 & $\begin{array}{l}\text { Novorapid FlexPen inj } 100 \\
\mathrm{iu} / \mathrm{ml}, 3 \mathrm{ml}\end{array}$ & $\begin{array}{l}\text { Analog insulin rapid acting inj } 100 \mathrm{UI} / \mathrm{ml} \text {, vial/cartridge } \\
\text { disposible/penfill cartridge (Insulin Aspart } \\
\text { (Analogue)), } 3 \mathrm{ml}\end{array}$ \\
\hline 25 & $\begin{array}{l}\text { Paracetamol inf } 10 \mathrm{mg} / \mathrm{mL} \text {, } \\
100 \mathrm{ml}\end{array}$ & Paracetamol inf $10 \mathrm{mg} / \mathrm{ml}, 100 \mathrm{ml}$ \\
\hline 26 & $\begin{array}{l}\text { Pegasys inj } 180 \mathrm{mcg} / 0,5 \mathrm{ml} \\
\text { prefilled syringe }\end{array}$ & Pegylated interferon $\alpha$-2a inj 180 mcg \\
\hline 27 & $\begin{array}{l}\text { Plasbumin-20 inf } 20 \%, 100 \\
\mathrm{ml}\end{array}$ & Human Albumin inf 20\%, $100 \mathrm{ml}$ \\
\hline 28 & Plasbumin-20 inf $20 \%, 50 \mathrm{ml}$ & Human Albumin inf 20\%, $50 \mathrm{ml}$ \\
\hline 29 & Plasbumin-5 inf $5 \%, 250 \mathrm{ml}$ & Human Albumin inf $5 \%, 250 \mathrm{ml}$ \\
\hline 30 & Ringer Laktat inf , $500 \mathrm{ml}$ & Ringer lactate inf, $500 \mathrm{ml}$ \\
\hline 31 & Sandostatin LAR inj $20 \mathrm{mg}$ & Octreotide inj 20 mg \\
\hline 32 & Sevoflurane liq , $250 \mathrm{~mL}$ & Sevoflurane sol \\
\hline 33 & Sindaxel inj $100 \mathrm{mg} / 16,67 \mathrm{ml}$ & Paclitaxel inj $100 \mathrm{mg} / 16.7 \mathrm{ml}$ \\
\hline 34 & Sindaxel inj $30 \mathrm{mg}, 5 \mathrm{ml}$ & Paclitaxel inj $30 \mathrm{mg} / 5 \mathrm{ml}$ \\
\hline 35 & Tamofen tab $10 \mathrm{mg}$ & Tamoxifen tab $10 \mathrm{mg}$ \\
\hline
\end{tabular}

2 
Perhitungan Safety Stock, Stok Minimal dan Stok Maksimal Obat

Hasil perhitungan safety stock, stok minimal dan stok maksimal disajikan dalam (Tabel III).

Pengaruh penerapan minimummaximum stock level pada pemesanan obat di intstalasi farmasi RSUP Dr. Sardjito dilihat nilai persediaan, nilai ITOR, nilai dan kejadian stock out sebelum dan sesudah intervensi dilakukan. Hasil perolehan nilai sebelum dan sesudah intervensi yang dilakukan, yaitu terjadi penurunan nilai persediaan, penurunan nilai ITOR menjadi ideal, penurunan nilai dan kejadian stock out (Tabel IV).

Berdasarkan Tabel 4. hasil total nilai persediaan di gudang farmasi sebelum intervensi adalah Rp.5.009.221.204 (sebelum bulan November 2018), hal ini menunjukkan tingginya nilai persediaan, akan tetapi setelah dilakukan intervensi nilai persediaan bulan Desember tahun 2018 menjadi turun sebesar Rp. 2.871.879.269. Penyesuaian jumlah pembelian sesuai dengan stok maksimal menjadi faktor penting pada hasil nilai persediaan di akhir tahun. Hasil uji statistik menggunakan Wilcoxon Signed Rank Test menunjukkan adanya signifikansi pengaruh penerapan metode minimum-maximum stock level dengan nilai $p=0,007, p<0,05$, hal ini menunjukkan adanya pengaruh efisiensi terhadap nilai persediaan di gudang farmasi RSUP Dr. Sardjito Yogyakarta. Pada penelitian lain yang dilakukan oleh Dampung (2018), menunjukkan bahwa dengan penerapan pengendalian dengan menggunakan metode MMSL (Minimum-Maximum Stock Level) di Apotik Umum Rumah Sakit Pelamonia Makassar untuk nilai stok akhir tahun sediaan farmasi menjadi lebih kecil jika dibandingkan sebelum penerapan pengendalian dengan menggunakan metode MMSL (MinimumMaximum Stock Level) ${ }^{16}$.

Pada Tabel IV terdapat hasil Inventory Turn Over Ratio (ITOR) mengalami penurunan yaitu dari 20,8 kali/tahun sebelum intervensi, dan sesudah intervensi menjadi $8,5 \mathrm{kali} /$ tahun, dan secara uji statistik menggunakan metoda Wilcoxon Signed Rank Test dengan nilai $p=$
0,003, $p<0,05$, hal ini menunjukkan adanya pengaruh penerapan metoda penelitian pada nilai ITOR. Efisiensi persediaan diukur pula dengan besaran nilai Inventory Turn Over Ratio (ITOR) yang didapat. Nilai TOR (Turn Over Ratio) semakin rendah (kecil) berarti terdapat stok yang belum terjual yang berakibat akan menghambat aliran kas sehingga berpengaruh terhadap keuntungan ${ }^{16}$. Periode pengadaan yang ditetapkan oleh Kepala Instalasi Farmasi Rumah Sakit Umum Pusat Dr. Sardjito yaitu pemesanan terjadwal (scheduled purchasing) tiap 3 bulan (90 hari) juga mempengaruhi hasil nilai Inventory Turn Over Ratio (ITOR). Pemesanan terjadwal ini mencegah terjadinya kelebihan pemesanan, dana yang disediakan juga tidak terlalu besar dan perkiraan penggunaan obat lebih tepat. Pada penerapan metode penelitian ini selama bulan Desember 2018 tidak ada pembelian atau pemesanan obat, sehingga mengakibatkan Inventory Turn Over Ratio (ITOR) menjadi turun. Hal ini sesuai menurut Quick, untuk sektor publik pemerintahan seperti rumah sakit pemerintah hal ini sejalan dikarenakan periode pengadaannya terjadwal setiap tahun ataupun triwulan ataupun tiap semester yang menjadikan ITOR menjadi lebih kecil dibandingkan dengan sektor swasta ${ }^{10}$.

Berdasarkan hasil penerapan minimummaximum stock level pada nilai stock out, terdapat hasil penurunan nilai stock out, yaitu sebelum intervensi sebesar Rp. 75.569.317 dan sesudah intervensi menjadi Rp. 46.346.300, hal ini menunjukkan adanya pengaruh nilai rupiah, tetapi hasil uji statistik menghasilkan nilai $p=0,068, p>0,05$, akan tetapi tidak adanya pengaruh secara statistik pada penerapan metoda minimum-maximum stock level pada nilai stockout.

Pada hasil kejadian atau frekuensi stockout sebelum intervensi ada 8 kali kejadian stockout dan hasil sesudah intervensi menjadi 2 kali kejadian stockout, serta hasil uji statistik menggunakan metoda Mc Nemar menunjukkan nilai $p=0,003, p<0,05$, hal ini menunjukkan adanya pengaruh penerapan metoda minimum-maximum stock level pada kejadian stockout. Pada rumah sakit 
Tabel IIIa. Perhitungan Safety Stock, Stok Minimal dan Stok Maksimal

\begin{tabular}{|c|c|c|c|c|c|c|c|c|c|}
\hline \multirow[t]{2}{*}{ No } & \multirow[t]{2}{*}{ Nama Obat } & \multirow{2}{*}{$\begin{array}{c}\text { Satuan } \\
\text { (per } \\
\text { Unit) } \\
\end{array}$} & \multirow{2}{*}{$\begin{array}{c}\text { Lead } \\
\text { Time } \\
\text { (Hari) } \\
\mathbf{x}\end{array}$} & \multirow{2}{*}{$\begin{array}{c}\text { Pakai } \\
\text { /Hari } \\
\text { (Unit) }\end{array}$} & \multirow{2}{*}{$\begin{array}{c}\begin{array}{c}\text { Safety } \\
\text { Stock } \\
\text { (Unit) }\end{array} \\
\mathrm{xy}\end{array}$} & \multirow{2}{*}{$\begin{array}{l}\begin{array}{l}\text { Smin } \\
\text { (Unit) }\end{array} \\
2 x y\end{array}$} & $\begin{array}{l}\text { PP } \\
\text { Hari) }\end{array}$ & \multirow{2}{*}{$\begin{array}{c}\begin{array}{c}\text { Smax } \\
\text { (Unit) }\end{array} \\
\begin{array}{c}2 x y+(x \\
\left.i^{*} y\right)\end{array}\end{array}$} & \multirow{2}{*}{$\begin{array}{c}\text { Jumlah } \\
\text { Beli } \\
\text { (Unit) }\end{array}$} \\
\hline & & & & & & & $x i$ & & \\
\hline 1 & Alimta inj $500 \mathrm{mg}$ & vial & 12 & 1 & 12 & 24 & 90 & 114 & 16 \\
\hline 2 & Aminofluid inf, $500 \mathrm{ml}$ & flabbot & 5 & 21 & 105 & 210 & 90 & 2100 & 2000 \\
\hline 3 & Aricept Evess tab $10 \mathrm{mg}$ & tablet & 11 & 80 & 880 & 1760 & 90 & 8960 & 8800 \\
\hline 4 & Aromasin tab $25 \mathrm{mg}$ & tablet & 7 & 157 & 1099 & 2198 & 90 & $\begin{array}{c}1632 \\
8\end{array}$ & 6600 \\
\hline 5 & $\begin{array}{l}\text { Avastin inj } 25 \mathrm{mg} / \mathrm{mL}, 4 \\
\mathrm{ml}\end{array}$ & vial & 7 & 5 & 35 & 70 & 90 & 520 & 520 \\
\hline 6 & Belloxa inj $100 \mathrm{mg}$ & vial & 3 & 4 & 12 & 24 & 90 & 384 & 384 \\
\hline 7 & $\begin{array}{l}\text { Clinimix N9G15E inf, } \\
1000 \mathrm{ml}\end{array}$ & flabbot & 12 & 9 & 108 & 216 & 90 & 1026 & 500 \\
\hline 8 & $\begin{array}{l}\text { Cytarabin DBL inj } 1 \mathrm{~g}, \\
10 \mathrm{~mL}\end{array}$ & vial & 5 & 2 & 10 & 20 & 90 & 200 & 0 \\
\hline 9 & $\begin{array}{l}\text { Erbitux inj } 5 \mathrm{mg} / \mathrm{mL}, 20 \\
\mathrm{ml}\end{array}$ & vial & 4 & 5 & 20 & 40 & 90 & 490 & 303 \\
\hline 10 & $\begin{array}{l}\text { Fentanyl inj } 50 \\
\mathrm{mcg} / \mathrm{mL}, 2 \mathrm{ml}\end{array}$ & ampul & 6 & 239 & 1434 & 2868 & 90 & $\begin{array}{c}2437 \\
8\end{array}$ & $\begin{array}{c}2270 \\
0\end{array}$ \\
\hline 11 & Ferriprox tab $500 \mathrm{mg}$ & tablet & 11 & 253 & 2783 & 5566 & 90 & $\begin{array}{c}2833 \\
6\end{array}$ & $\begin{array}{c}1420 \\
0\end{array}$ \\
\hline 12 & $\begin{array}{l}\text { Gammaraas inj } 2.5 \mathrm{~g}, 50 \\
\mathrm{ml}\end{array}$ & vial & 2 & 1 & 2 & 4 & 90 & 94 & 94 \\
\hline 13 & Gemedac inj 1000 mg & vial & 5 & 2 & 10 & 20 & 90 & 200 & 68 \\
\hline 14 & Glivec tab 100 mg & tablet & 12 & 403 & 4836 & 9672 & 90 & $\begin{array}{c}4594 \\
2\end{array}$ & $\begin{array}{c}4500 \\
0\end{array}$ \\
\hline 15 & Haemoctin inj 1000 IU & vial & 5 & 1 & 5 & 10 & 90 & 100 & 46 \\
\hline 16 & Holoxan inj $1 \mathrm{~g}$ & vial & 10 & 6 & 60 & 120 & 90 & 660 & 155 \\
\hline 17 & $\begin{array}{l}\text { Human Albumin } \\
\text { Biotest inf } 20 \%, 100 \mathrm{ml}\end{array}$ & vial & 7 & 3 & 21 & 42 & 90 & 312 & 180 \\
\hline 18 & Koate inj 1000 IU & vial & 3 & 2 & 6 & 12 & 90 & 192 & 100 \\
\hline 19 & Koate inj $500 \mathrm{IU}$ & vial & 2 & 2 & 4 & 8 & 90 & 188 & 188 \\
\hline 20 & $\begin{array}{l}\text { Mabthera inj } 100 \text { mg, } 10 \\
\text { ml }\end{array}$ & vial & 9 & 2 & 18 & 36 & 90 & 216 & 216 \\
\hline 21 & $\begin{array}{l}\text { Mabthera inj } 500 \text { mg, } 50 \\
\mathrm{ml}\end{array}$ & vial & 15 & 2 & 30 & 60 & 90 & 240 & 60 \\
\hline 22 & Mycamine inj 50 mg & vial & 13 & 8 & 104 & 208 & 90 & 928 & 360 \\
\hline 23 & $\begin{array}{l}\text { Novomix } 30 \text { FlexPen inj } \\
100 \mathrm{iu} / \mathrm{ml}, 3 \mathrm{ml}\end{array}$ & vial & 5 & 11 & 55 & 110 & 90 & 1100 & 1100 \\
\hline 24 & $\begin{array}{l}\text { Novorapid FlexPen inj } \\
100 \mathrm{iu} / \mathrm{ml}, 3 \mathrm{ml}\end{array}$ & vial & 5 & 22 & 110 & 220 & 90 & 2200 & 2200 \\
\hline 25 & $\begin{array}{l}\text { Paracetamol inf } 10 \\
\mathrm{mg} / \mathrm{mL}, 100 \mathrm{~mL}\end{array}$ & vial & 9 & 185 & 1665 & 3330 & 90 & $\begin{array}{c}1998 \\
0\end{array}$ & $\begin{array}{c}1900 \\
0\end{array}$ \\
\hline 26 & $\begin{array}{l}\text { Pegasys inj } 180 \mathrm{mcg} / 0,5 \\
\text { ml prefilled syringe }\end{array}$ & vial & 8 & 1 & 8 & 16 & 90 & 106 & 0 \\
\hline
\end{tabular}


Tabel IIIb. Perhitungan Safety Stock, Stok Minimal dan Stok Maksimal

\begin{tabular}{|c|c|c|c|c|c|c|c|c|c|}
\hline \multirow[t]{2}{*}{ No } & \multirow[t]{2}{*}{ Nama Obat } & $\begin{array}{c}\text { Satuan } \\
\text { (per } \\
\text { Unit) }\end{array}$ & $\begin{array}{c}\text { Lead } \\
\text { Time } \\
\text { (Hari) }\end{array}$ & $\begin{array}{l}\text { Pakai } \\
\text { /Hari } \\
\text { (Unit) }\end{array}$ & $\begin{array}{l}\text { Safety } \\
\text { Stock } \\
\text { (Unit) }\end{array}$ & $\begin{array}{l}\text { Smin } \\
\text { (Unit) }\end{array}$ & $\begin{array}{c}\text { PP } \\
\text { (Hari) }\end{array}$ & $\begin{array}{l}\text { Smax } \\
\text { (Unit) }\end{array}$ & \multirow{2}{*}{$\begin{array}{c}\text { Jumlah } \\
\text { Beli } \\
\text { (Unit) }\end{array}$} \\
\hline & & & $\mathbf{x}$ & $\mathbf{y}$ & $x y$ & $2 x y$ & $x i$ & $\begin{array}{c}2 x y+(x \\
\left.i^{*} y\right)\end{array}$ & \\
\hline 27 & $\begin{array}{l}\text { Plasbumin-20 inf } 20 \% \text {, } \\
100 \mathrm{~mL}\end{array}$ & vial & 6 & 5 & 30 & 60 & 90 & 510 & 510 \\
\hline 28 & $\begin{array}{l}\text { Plasbumin-20 inf } 20 \% \text {, } \\
50 \mathrm{~mL}\end{array}$ & vial & 6 & 4 & 24 & 48 & 90 & 408 & 400 \\
\hline 29 & $\begin{array}{l}\text { Plasbumin-5 inf } 5 \% \text {, } \\
250 \mathrm{~mL}\end{array}$ & vial & 2 & 3 & 6 & 12 & 90 & 282 & 30 \\
\hline 30 & $\begin{array}{l}\text { Ringer Laktat inf, } 500 \\
\mathrm{~mL}\end{array}$ & flabbot & 8 & 185 & 1480 & 2960 & 90 & $\begin{array}{c}1961 \\
0\end{array}$ & $\begin{array}{c}1900 \\
0\end{array}$ \\
\hline 31 & $\begin{array}{l}\text { Sandostatin LAR inj } 20 \\
\mathrm{mg}\end{array}$ & vial & 4 & 1 & 4 & 8 & 90 & 98 & 19 \\
\hline 32 & Sevoflurane liq, $250 \mathrm{~mL}$ & $\mathrm{ml}$ & 3 & $\begin{array}{c}137 \\
1\end{array}$ & 4113 & 8226 & 90 & $\begin{array}{c}1316 \\
16\end{array}$ & $\begin{array}{c}9400 \\
0\end{array}$ \\
\hline 33 & $\begin{array}{l}\text { Sindaxel inj } 100 \\
\mathrm{mg} / 16,67 \mathrm{ml}\end{array}$ & vial & 5 & 10 & 50 & 100 & 90 & 1000 & 680 \\
\hline 34 & $\begin{array}{l}\text { Sindaxel inj } 30 \mathrm{mg}, 5 \\
\mathrm{~mL}\end{array}$ & vial & 9 & 31 & 279 & 558 & 90 & 3348 & 3300 \\
\hline 35 & Tamofen tab 10 mg & tablet & 2 & 629 & 1258 & 2516 & 90 & $\begin{array}{c}5912 \\
6\end{array}$ & $\begin{array}{c}4002 \\
0\end{array}$ \\
\hline
\end{tabular}

Tabel IV. Perbedaan Nilai Persediaan, ITOR, Nilai Serta Kejadian Stockout Sebelum dan Sesudah Intervensi Metode Pemesanan Minimum-Maximum Stock Level

\begin{tabular}{lllcc}
\hline & $\begin{array}{l}\text { Sebelum } \\
\text { Intervensi }\end{array}$ & Sesudah Intervensi & $\begin{array}{c}\text { Hasil Uji } \\
\text { Statistik }\end{array}$ & Keterangan \\
\cline { 3 - 5 } & & & Nilai $\boldsymbol{p}$ & Metode Uji \\
\hline Nilai Persediaan & Rp. 5.009.221.204 & Rp. 2.871 .879 .269 & $0,007^{*}$ & Wilcoxon Signed \\
ITOR & 20,776 kali/tahun & 8,494 kali/tahun & $0,003^{*}$ & Rank Test \\
Nilai Stockout & Rp. 75.569.317 & Rp. 46.346 .300 & $0,068 \#$ & Mc Nemar \\
Kejadian Stockout & 8 kali & 2 kali & $0,031^{*}$ & Mc
\end{tabular}

Sumber : Data Logistik Instalasi Farmasi RSUP Dr. Sardjito.

Keterangan: Nilai $p^{*}=$ nilai $\mathrm{p}<0,05$, signifikansi pengaruh minimum-maximum stock level $(\mathrm{MMSL})$; Nilai $p \#=$ nilai $p>0,05$, tidak adanya signifikansi pegaruh minimum-maximum stock level (MMSL).

pemerintah seperti halnya Rumah Sakit Umum Pusat Dr. Sardjito, nilai stock out tidak begitu berpengaruh pada pengurangan pendapatan ataupun kerugian rumah sakit karena obat yang mengalami stock out tersebut masih ada substitusi nama dagang yang lain, dengan kata lain obat tersebut dapat digantikan dengan obat yang lain, sehingga ketiadaan stok tidak berpengaruh pada pendapatan rumah sakit. Akan tetapi lain halnya dengan hasil analisa uji statistik pada frekuensi kejadian stock out dengan menggunkan uji Mc Nemar yang menghasilkan uji statistik berpengaruh 
signifikan. Nilai stockout dan stagnant obat menjadi perhatian juga pada penelitian yang dilakukan oleh Febreani (2016), karena pengadaan obat yang terjadi diluar perencanaan kebutuhan yang sudah ditetapkan dimana belum memiliki batas minimal dan maksimal yang pasti akan mengakibatkan terjadinya stagnant dan stockout obat. ${ }^{17}$ Ketepatan perencanaan obat juga berpengaruh pada penerapan metode pengendalian pemesanan, oleh karena itu instalasi farmasi harus memastikan perencanaan dilakukan dengan tepat. Hal ini sejalan dengan penelitian yang dilakukan oleh Widhayunita bahwa ketepatan perencanaan juga menjadi faktor penting dalam penerapan satu metode pengendalian persediaan obat askes dengan analisis abc dan metode Economic Order Quantity (EOQ) di Instalasi Farmasi RSUD Dr. Saiful Anwar Malang. ${ }^{18}$

Penerapan metode minimum-maximum stock level dapat digunakan sebagai metode pengendalian pemesanan pada 35 jenis obat kategori A kriteria tertentu di Instalasi Farmasi Rumah Sakit Umum Pusat Dr. Sardjito Yogyakarta. Metode minimummaximum stock level ini dapat dimasukkan dalam Sistem Informasi Manajemen Rumah Sakit (billing system), sehingga dapat mempermudah petugas gudang farmasi dalam penerapan metode tersebut. Penelitian ini hanya sebagai penelitian awal untuk penerapan satu metode pengendalian pemesanan obat di instalasi farmasi, sehingga diperlukan penelitian lanjutan terkait metode pengendalian persediaan yang lain dan kendala penerapan metode di akhir tahun dapat diminimalisir sehingga pengendalian persediaan di gudang farmasi menjadi lebih optimal.

\section{KESIMPULAN}

Hasil penerapan metode minimummaximum stock level memberikan dampak positif pada efisiensi persediaan obat yaitu adanya penurunan nilai persediaan dan nilai ITOR (Inventory Turn Over Ratio) sesuai dengan yang diharapkan, serta penerapan metode minimum-maximum stock level berpengaruh pada efektifitas persediaan obat yaitu adanya penurunan angka kejadian stockout sehingga hasil ini sangat berpengaruh pada efisiensi dan efektivitas investasi yang dilakukan oleh Instalasi Farmasi Rumah Sakit Umum Pusat Dr. Sardjito Yogyakarta.

\section{UCAPAN TERIMA KASIH}

Terima kasih kepada Rumah Sakit Umum Pusat Dr. Sardjito yang telah memberikan ijin kepada penulis menyelesaikan karya tulis ini sebagai syarat kelulusan studi Magister Manajemen Farmasi di Fakultas Farmasi Universitas Gadjah Mada Yogyakarta.

\section{DAFTAR PUSTAKA}

1. Kementerian Kesehatan. Peraturan Menteri Kesehatan Republik Indonesia Nomor 72, Tentang Standar Pelayanan Kefarmasian Di Rumah Sakit. 2016.

2. Kumalasari A., Rochmah. Pengendalian Persediaan Obat Generik Dengan Metode MMSL (Minimum-Maximum Stcok Level) Di Unit Farmasi Rumah Sakit Islam Surabaya. Manajemen, J Stikes, Kesehat Rs, Yayasan. 2016;2(2):143152.

3. Prabowo P., Satibi., Pamudji. Analisis Faktor-Faktor Yang Mempengaruhi Ketersediaan Obat Era JKN Pada Rumah Sakit Umum Daerah. J Manaj dan Pelayanan Farm. 2015:213-218. doi:2443-2946

4. Manivel P., Ranganathan R. Prioritized ABC-FSN Analysis of Inventory Management in Private and Hospital Pharmacy Followed By Questionnaire. Int Res J Pharm. 2017;7(12):104-113.

5. Hartih AN., Satibi., Widodo. Penerapan Metode Economic Order Quantity Dan Reorder Point Dalam Meningkatkan Efisiensi Persediaan Obat Reguler Di Instalasi Farmasi Rumah Sakit. J Manaj dan Pelayanan Farm. 2013;3(4):249-254.

6. Satibi. Manajemen Obat Di Rumah Sakit. Ketiga. Yogyakarta: Gadjah Mada University Press; 2017.

7. Rosmania AF., Supriyanto S. Analisis 
Pengelolaan Obat Sebagai Dasar Pengendalian Safety Stock Pada Stagnant Dan Stockout Obat. J Adm Kesehat Indones. 2015;3(23-6):1-10.

8. Sheina B., Umam MR. Penyimpanan Obat Di Gudang Instalasi Farmasi RS PKU Muhammadiyah Yogyakarta Unit I. J Kes Mas UAD ISSN 1978-0575. 2010;4(1):1-75.

9. Leung NHZ., Chen A., Yadav P., Gallien J. The Impact of Inventory Management On Stock-Outs of Essential Drugs in Sub-Saharan Africa: Secondary Analysis of A Field Experiment in Zambia. PLoS One. 2016;11(5):1-18.

10. Management Sciences for Health. Pharmaceutical Supply Strategies. MDS-3 Manag Access to Med Heal Technol. 2012. https://www.msh.org/sites/msh.org/file s/mds3-ch08-supply-strategiesmar2012.pdf.

11. Laeiddee C. Improvement of Pre Order Point for Drug Inventory Management at Ramathibodi Hospital. Research Thesis. Mahidol University. Thailand. 2010.

12. WHO. Management Sciences for Health. Managing Procurement. MDS-3 Manag Access to Med Heal Technol. 2012:18.1-18.27.
13. Shinta YM. Evaluasi Pemasok Obat Di Instalasi Farmasi RSUD Achmad Mochtar Bukittinggi. Tesis. Universitas Andalas. Bukittinggi. 2016.

14. Onut K;Elif. Long Term Supplier Slecetion Using a Combined Fuzzy MCDM Approach: A Case Study for Telecommunication Company, Expert Systems with Applications. Int J Achieve. 2009;36(2):3887-3895.

15. Lestyowati J. Analisis Permasalahan EPurchasing Dalam Pengadaan Barang Dan Jasa Satuan Kerja. J Simp Nas Keuang Negara. 2018:669-695.

16. Dampung V., Maidin., Mardiana. Penerapan Metode Konsumsi Dengan Peramalan, EOQ, MMSL Dan Analisis ABC-VEN Dalam Manajemen Perbekalan Farmasi Di Rumah Sakit Pelamonia Makassar. Media Farm. 2018;XIV(1):97-104.

17. Febreani HS;Chalidyanto D. Pengelolaan Sediaan Obat Pada Logistik Farmasi Rumah Sakit Umum Tipe B Di Jawa Timur. J Adm Kesehat Indones. 2016;4(2):136-145.

18. Widhayunita L. Pengendalian Persediaan Obat Askes Dengan Analisis ABC Dan Metode Economic Order Quantity Di Instalasi Farmasi RSUD Dr. Saiful Anwar Malang. J Manaj dan Pelayanan Farm. 2014. 